\title{
Samtalen mellem Grundtvig og Kierkegaard
}

\section{Af Otto Bertelsen}

Henrik Wigh-Poulsen, Hans Grishauge, Niels Jørgen Cappelørn, Joakim Garff og Henning Nielsen (red.), Grundtvig - Kierkegaard. En samtale på høje tid (Forlaget Vartov, København, 2002), 224 s.

I maj 2002 afholdtes i København en Grundtvig-Kierkegaard uge, fra hvilken 13 af foredragene er blevet samlet i denne bog. En anmeldelse af en sådan bog bliver en slags kludetæppearbejde. Nogle af kludene vil måske på grund af anmelderens sym- og antipatier blive lidt misfarvede, men jeg vil forsøge at gøre det så objektivt som muligt.

\section{Når der bliver mere ud af mindre: Grundtvigs menneskesyn}

Samlingen indledes af Niels Henrik Gregersen med et meget vel formuleret og vel gennemtænkt foredrag: 'Når der bliver mere ud af mindre: Grundtvigs menneskesyn', der skildrer Grundtvigs trinitariske opfattelse af det kristne menneskeliv, fra hvilket Gud gennem sin frelseshandling høster lovsangens overskud. "Der er et overskud, der flyder fra Gud over til mennesket, og hér opstår et nyt overskud, der flyder videre ud mod næsten og tilbage i Gud" (s. 12). Grundtvig skelner som Kierkegaard mellem legeme, sjæl og ånd og forstår som Kierkegaard

det åndelige som det, der overhovedet gør et menneske til et menneske. Men til forskel fra Kierkegaard opstår det åndelige ikke først ved menneskets åndelige opvågning. Menneskets opvækkelse bliver til som en opdagelse af en større verden - ikke som selvbevidstgørelse (s. 15).

Denne større verden er i sidste ende kristendommen, der møder mennesket i form af trosbekendelse og dåb, af Fadervor og af nadveren, der svarer til tro, håb og kærlighed, og som kommer til udvortes udtryk i fred, retfærdighed og glæde. Således er hele Grundtvigs teologi præget af en trinitarisme, der ligger fjernt fra Kierkegaards absolutte paradoks: Guden, der bliver menneske.

Modsigelsen - en grundtvigsk diagnose.

Ebbe Kløvedal Reich anfører i 'Modsigelsen - en grundtvigsk diagnose', 
at der i opfattelsen af forholdet mellem Grundtvig og Kierkegaard findes to skoler: en medierende skole, hvori blandt andet anmelderen anbringes, og en kontrasterende skole, repræsenteret af Vilh. Grønbech, Knud Hansen og K. E. Løgstrup. Reich tilslutter sig den sidste, men når man betragter hans forbundsfæller, bliver man betænkelig, for både Knud Hansen og Løgstrup har nogle fejlagtige forestillinger om Kierkegaard (jfr. Soren Kierkegaard laest af K. Olesen Larsen, bd. I). Når man fra den medierende skoles side påstår, at Kierkegaard under kirkekampen har håbet på støtte fra grundtvigianerne, er det ifølge Reich at "stille den kamp helt på hovedet", for det var Grundtvig og hans menigheds- og kirkesyn, der var "den vigtigste modstander" (s. 40). Der må skulle nogle specielt grundtvigske briller til for at få det ud af kirkekampen. I det hele fastholder Reich den gamle grundtvigske opfattelse, at der er en uoverstigelig modsætning mellem Grundtvig og Kierkegaard.

\section{For Gud er Alt muligt}

Pia Søltoft har et meget skarpt øje for de mange små sprækker i Kierkegaards teologiske udsagn, der antyder, at han i sit kristendomssyn ligger Grundtvig nærmere end normalt antaget. Udgangspunktet for hendes foredrag: 'For Gud er Alt muligt' er Kierkegaards opfattelse af Kristus som det absolutte paradoks. Det er den tanke, der bærer hele forfatterskabet. For Grundtvig spiller Kristusparadokset ikke den helt store rolle, men Grundtvig ved dog, at livet er en paradoksal kamp mellem lys og mørke, liv og død, Gud og Djævel. Derfor bliver afstanden til Kierkegaard på dette punkt ikke så stor. Pia Søltoft viser i øvrigt, at der i forskellige sammenhænge, hvor man har postuleret en uoverstigelig forskel mellem Grundtvig og Kierkegaard, er væsentlige lighedspunkter. Det gælder forholdet mellem de menneskelige og det kristelige, forholdet mellem lov og evangelium og væksttanken contra efterfølgelsestanken. Ikke mindst vigtigt er det, at der består en konsensus mellem dem i opfattelsen af nadveren.

\section{Sjaele og kroppe i tusindtal}

I 'Sjæle og kroppe i tusindtal' indleder Kim Arne Pedersen med at vise, hvordan grundtvigsk prægede tænkere som Knud Hansen, K. E. Løgstrup og Kaj Thaning har afvist Kierkegaard. De har været præget af religionshistorikeren Vilhelm Grønbech, der skrev: 
Medens Kierkegaaard vender ansigtet bagud og i sit forfatterskab synger dødssangen over en udlevet kultur, skuer Grundtvig fremad mod et nyt rige hinsides både protestantisme og katolicisme (s. 61).

Kim Arne Pedersen forsøger at blotlægge, hvorledes Grundtvigs "kirkesyn eller menighedsteologi nok står i modsætning til Kierkegaards fokusering på 'hin Enkelte', men at de to store tænkere trods dette er fælles om en trichotomisk, det vil sige treleddet antropologi" (s. 65), der for Grundtvig er udtryk for menneskets gudbilledlighed. I flere forskellige henseender svarer menneskets legeme, sjæl og ånd til Faderen, Sønnen og Helligånden. Kierkegaard derimod drømmer ikke et øjeblik om at sætte sin trichotomi i forbindelse med treenigheder, som for ham ikke spiller nogen afgørende dogmatisk rolle. Det gør derimod dens virkninger: troen bliver til ved et "skabelsens mirakel" (Helligånden), og Kristus er det absolutte paradoks, guden i tiden (Fader og Søn). [Anmelderens bemærkning].

I menighedssynet synes forskellen mellem Grundtvig og Kierkegaard nærmest uoverstigelig. For Kierkegaard er menigheden en menighed af "hin Enkelte". For Grundtvig er menigheden en forud given virkelighed. Sluttelig berøres sammenhængen mellem "Den christelige Børnelærdom" og kirkekampen, der gjorde et meget stærkt indtryk på Grundtvig. Kim Arne Pedersen konkluderer:

Grundtvig og Kierkegaard rendyrker i deres teologi og filosofi begge væsentlige aspekter af den kristne tradition, og i den nutidige teologs samtale med traditionen er der behov for at orientere sig ud fra begge forfatterskaber (s. 86).

\section{Grundtvigs vej fra studerekammeret til gudstjenesten}

I et meget klart og let forståeligt foredrag: 'Grundtvigs vej fra studerekammeret til gudstjenesten' skildrer Kresten Drejergaard, hvordan Grundtvigs kirkelige anskuelse er blevet til, og hvordan den udmunder i opfattelsen af gudstjenesten som inkarnationens sted, det sted, hvor Kristus møder os og taler til os, i særdeleshed ved dåb og nadver. Her står Grundtvig og Kierkegaard i фvrigt hinanden meget nær. Også for Kierkegaard er nadveren det nutidige inkarnationssted. 


\section{Grundtvigs kirkesyn}

Morten Kvist indleder sit foredrag 'Grundtvigs kirkesyn' med følgende linier: "At drage konsekvenser af Grundtvigs kirkesyn er ikke nogen simpel opgave. Udgangspunktet er i dag et andet, og vi har ikke uden videre problemfællesskab med Grundtvig" (s. 111). Det er så sandt, som det er sagt. Efter en gennemgang af den nuværende kirkelige og kulturelle situation beskriver han, hvori Grundtvigs mageløse opdagelse, senere kaldet den kirkelige anskuelse, består. Derved når han frem til, at gudstjenestens kerne er sakramenterne. I denne forbindelse kommer han med følgende næsten kierkegaardske bemærkning:

Det sakramentale mysterium ligger ikke i indvielsen af dåbsvandet eller brødets og vinens forvandling i nadveren. Det ligger derimod i hjerternes forvandling ved modtagelsen af sakramenterne (s. 119).

I artiklens slutning hedder det: “At se og møde den opstandne er dåbens og nadverens værk i os og iblandt os. Det er opstandelsen, som gådefuldt og virkeligt finder sted. Her handler Gud virkeligt med mennesket" (s. 122).

Anmelderen kan her ikke dy sig for at citere Kierkegaard:

Vel skal nemlig en Prædiken ogsaa vidne om Ham, forkynde Hans Ord og Hans Lære, men derfor er en Prædiken dog ikke Hans Røst. Ved Alteret derimod er det Hans Røst, Du skal høre. Om et andet Menneske sagde Dig det, hvad der skal siges ved Alteret, hvis alle Mennesker ville forene sig om at sige Dig det - dersom Du ikke hører Hans Røst, da gik Du forgjeves til Alters (Christelige Taler S. V. X, s. 278).

Hverken Morten Kvist eller Drejergaard giver udtryk for, hvor nær de i deres sakramentale gudstjenesteforståelse står ved Kierkegaard.

\section{Det forpligtede liv - om at vare en del af en historisk tradition}

Britta Schall Holberg fortæller i sit foredrag: 'Det forpligtede liv - om at være en del af en historisk tradition' om, hvordan hun ret sent i livet opdagede, "at Grundtvig ubevidst har præget så stor en del af de ting, man var optaget af, og som spillede den allerstørste rolle for en" (s. 127). Hun har i фvrigt en række betragtninger om, hvori det folkelige består. De munder ud i, at det folkelige gør mennesker ansvarlige. "Dermed er der mere linje mellem Grundtvig og Kierkegaard, end vi har villet se. De taler 
begge om et menneske af adel og lige værdighed" (s. 130). Det er selvfølgelig sandt nok, men ellers sporer man ikke megen dialog mellem Grundtvig og Kierkegaard hos Britta Schall Holberg.

Kierkegaard mod Konstitutionen - 'Medicin mod en Frihedsruus'

I 'Kierkegaard mod Konstitutionen - 'Medicin mod en Frihedsruus' leverer Peter Tudvad et fremragende bidrag til samtalen mellem Grundtvig og Kierkegaard. Her kommer de virkelig begge til orde, selvom Kierkegaard nok må siges at beholde det sidste ord. I den første del af foredraget skildres Kierkegaards syn på demokratiet, der rummer den store fare at blive til et "Abstractum, 100.000 brummende U-Mennesker" (s. 135). Så er en mådelig regent trods alt bedre.

Den nye liberale regering af $1848 \varnothing$ nskede politisk lighed mellem borgerne og mente at kunne opnå denne ved at stå sammen mod den tyske trussel. Men Kierkegaard understreger meget klart i Kjerlighedens Gjerninger, at man aldrig ad politisk vej kan nå til lighed:

Kun det Religieuse kan ved Evighedens Hjælp indtil det Sidste gjennemføre Menneske-Lighed, den gudelige, den væsentlige, den ikke-verdslige, den sande, den eneste mulige Menneske-Lighed (s. 139).

Samtalen mellem Grundtvig og Kierkegaard startes hos Tudvad med et citat af Grundtvig fra Dansk Kirketidende (som Kierkegaard abonnerede på og også læste). Grundtvig skriver, at

den Danske Folkeligheds Død er Folkets aandelige Død, der maa helbredes ved Folkelighedens Opreisning, førend der, uden som hen i Veiret, kan tales til og med Folket om levende Christelighed (s. 144).

Tudvad har ved at sammenstille Grundtvigs artikel i Dansk Kirketidende med nr. 2 af Christelige Taler ( $\mathrm{i}$ 'Tanker som saare bagfra til Opbyggelse'), der handler om Simon Peter, gjort et veritabelt kup. Kierkegaard skriver:

Han forlod Slaegt og Venner og Jaevnlige, de Begreber og Forestillinger, i hvilke hans Omgangskreds har havt deres Liv, han blev mere fremmed for dem end Den er, der taler et fremmed Sprog ... Han forlod Fadrenes Tro, dermed Folket, som han tilhorte, Fodelandet, hvis Kjerlighed binder med de stcerkeste Baand (s. 145-146). 
Begge passager er klare hentydninger til Grundtvigs artikel, hvilket bogstaveligt understreges ved, at de er spatierede, en fremgangsmåde, som Kierkegaard sjældent anvendte, men som han hånede Grundtvig for at bruge til overmål.

Her er en tydelig modstilling mellem Grundtvigs påstand om, at det kristne evangelium kun kan forkyndes for et "levende" folk, og Kierkegaards grundtanke, at det kun kan forkyndes for "hiin Enkelte".

I januar 1850 bemærker Kierkegaard i sin journal:

Det var aabenbart et Moment med i Christi Død, at han negtede Nationaliteten, at ville have med den at gjøre. Nu ere de Orthodoxe de ægte Nationale; man laver nu Theorier om christelige Stater og christelige Folk (s. 147).

Som en konsekvens af sit syn på det nationale ønskede Kierkegaard forbindelsen mellem kirke og stat og mellem kirke og monark strøget af grundloven af 1849 .

\section{Det politiske hos Kierkegaard og Grundtvig}

Svend Auken indleder sit foredrag: 'Det politiske hos Kierkegaard og Grundtvig' med en meget levende beskrivelse af den utrolige stank og larm, under hvilken Grundtvigs og Kierkegaards og i det hele taget guldaldertidens tænkning og malerkunst blev til. Han peger på, at fælles for Grundtvig og Kierkegaard er "Opgøret med den officielle kirkes rationalisme" og deres "søgen efter den personlige sandhed". Politisk er de begge tilhængere af enevælden. Grundtvig mener, at borgerne endnu ikke er modne til demokratiet, medens Kierkegaard pessimistisk mener, at de aldrig bliver det. Grundtvig får gennem sin rejse til England "sans for den teknologiske dynamik, men også for kapitalismens forkrøbling af det menneskelige samfund" (s. 152). "Kierkegaard har aldrig haft politisk betydning" (s. 154). "For Kierkegaard var det disharmonierne i den sjælelige arkitektur, der pådrog sig interesse - ikke mangler i samfundets sociale struktur" (s. 154). Auken konkluderer, at "Kierkegaard og Grundtvig har en aktualitet i vores livsnødvendige debat om demokrati og folkeliv i Danmark" (s. 157).

\section{Den enkelte og faellesskabet}

Marianne Jelveds foredrag: 'Den enkelte og fællesskabet' har ikke megen forbindelse med dialogen mellem Grundtvig og Kierkegaard. Hun fastslår 
ganske vist, at "det er tydeligt, at Kierkegaard og Grundtvig begge har været grundlag for værdier og principper, for mål og midler" (s. 161) ved dannelsen af Det Radikale Venstre, men hvorledes de har været det, fortæller hun kun lidt om.

\section{Melankoli og profeti. Om Grundtvig, Lundbye og guldalderkunsten}

I et meget fængslende foredrag: 'Melankoli og profeti. Om Grundtvig, Lundbye og guldalderkunsten' beretter Henrik Wigh-Poulsen om Lundbyes forhold til Grundtvig - og Kierkegaard. Lundbye skriver om Grundtvig: "Naar jeg gaaer i Kirke hører jeg helst Grundtvig, (...) Han er den eneste der kan trøste for den Modløshed og det Vildrede, hvori vi leve" (s. 167). Men også Kierkegaard finder han hjælp hos. Efter at have læst Stadier paa Livets Vei fortæller han:

Søren er min Ven, selv om jeg kun forstaar hvert andet Ord, jeg kan dog forstaa Meningen i det hele i hans Kjærlighedshistorie, og han giver mig enkeltviis saa mangen velfortjent Ørefigen, at jeg virkelig er ham højst taknemmelig (s. 169).

Wigh-Poulsen beskæftiger sig særligt med Grundtvigs påvirkning af billedkunsten, der dog først viser sig et par generationer senere, for eksempel hos Skovgaardbrødrene. På Grundtvigs egen tid er der snarere tale om "en masse falles påvirkninger, en bred europæisk-romantisk arv, der præger dem alle - Grundtvig såvel som kunstnerne" (s. 170). Med Mands Minde-foredragene 1838 træder Grundtvig fra at beskæftige sig med fortiden ind i nutiden. Nu har han "i dagens begivenheder og det politiske røre genkendt, hvad der før har begejstret" ham "i den store fortid". Nu kan han erklære, at "Gyldenaaret allerede [er] født" (s. 177). Fra 1843 har vi Lundbyes kendte tegning: N. F. S. Grundtvig taler for en forsamling $i$ Borchs Kollegium. Men Grundtvigs tale om gyldenåret kunne ikke virkelig gribe Lundbye. Hvis han havde kendt Kierkegaards hvasse kritik af Grundtvigs syner, havde han nok snarest givet Kierkegaard ret.

Wigh-Poulsen konkluderer:

Grundtvig lod ham [Lundbye] og hans samtidige se sig selv som indfældede og hjemmehørende i - ikke alene slægtens, folkets og menighedens fællesskab - men i sidste ende også Guds frelsesplan. Kierkegaard, derimod, belærte Lundbye om dette at give afkald på 
sine lykkedrømme og kærlighedslængsel, tage sin ensomhed på sig som skæbne, elske sit tungsind og i dette vinde indsigten - leve frem for at skabe, med andre ord, Lundbye levede udmærket med dem begge. Ligesom vi vel gør (s. 184).

\section{Om det aestetiske hos Kierkegaard}

Joakim Garff, der har en meget elegant penneføring, har givet sit foredrag titlen: 'Om det æstetiske hos Kierkegaard.' Han indleder med at mindes Søren Kierkegaard Selskabet for 20 år siden, da det var kronet af "et bølgende hav af blåt damehår, der enkelte steder blev brudt af en hårløs isse eller to" (s. 187). En erindring, som anmelderen også har, dog indbefattet en ung cand.theol. Garff. Dengang var det ikke det æstetiske, men stadieteorien, der stod på dagsordenen. Men nu er det æstetikeren, interessen samler sig om, for "æstetikeren er forfatterskabets moderne stemme" (s. 192), hvilket for eksempel viser sig i en sætning som denne: "Vor Tid har tabt alle substantielle Bestemmelser af Familie, Stat, Slægt; den maa ganske overlade det enkelte Individ til sig selv, saaledes at det i strængere Forstand bliver sin egen Skaber" (s. 191).

I afsnittet: 'Det æstetiske som medium' har Garff følgende fine bemærkninger:

Kierkegaard dyrkede ikke blot stilen, han var også billeddyrker, ikonodul. Hans værker vinder således fremdrift ved dynamiske omslag mellem billede og begreb. (...) Næppe har man været indlagt til en kompliceret, dialektisk operation, før man sendes på et rekreativt ophold i en skrift, der udbreder sig ekspressivt, underligt oplyst indefra (s. 194).

I København var det moderne at gøre grin med Grundtvig, men "i disciplinen grundtvigske grovheder har Kierkegaard dog ubetinget rekorden" (s. 197). Ikke desto mindre har han også en vis respekt for Grundtvig, som han kalder et geni, en betegnelse, han ellers kun anvender om sig selv.

Kierkegaards forfatterskab slutter i 1855 med en "enmandsrevolution", der er "et korrektiv til "det Bestaaende", men den er også "et korrektiv til hans eget forfatterskab, hvis pseudonyme bugtaleri slår om i den ultimative personlige udsigelse" (s. 199). I Synspunktet for min Forfattervirksomhed understreger Kierkegaard, at forfatterskabet ikke må læses æstetisk-biografisk, men derimod skal tolkes religiøst. Garff 
bemærker,

at når Kierkegaard så ihærdigt modsætter sig en æstetisk læsning af forfatterskabet, så er det, logisk set, fordi han allerede selv har foretaget en sådan læsning og derfor ved, at den æstetiske læsning - hvor forfejlet den end måtte være - kunne komme på tale (s. 201).

Garff slutter med at ønske, at der må komme en læsning,

der bærer vidnesbyrd om, at det tilsyneladende mest uanvendelige i de kierkegaardske tekster, alt det marginale og fragmentariske, nok i virkeligheden er det mest uundværlige, fordi det modsætter sig ethvert forsøg på at instrumentalisere tekseterne og dermed gøre sig færdige med dem (s. 203).

\section{Tålt ophold-om den autonome musik, Grundtvig og Kierkegaard $i$ et nutidsperspektiv}

For en toned $\varnothing v$ anmelder er der meget i Sven Erik Werners 'Tålt ophold - om den autonome musik, Grundtvig og Kierkegaard i et nutidsperspektiv', som ligger uden for hans horisont. Derimod er han meget enig med Werner i,

at lighederne mellem Grundtvigs og Kierkegaards projekter var større end forskellene. Begge ville de ud fra forskellige positioner 'vække et folk af dvale', (...) og begge ville de det frie, selvberoende og ansvarlige menneske. (...) Der var kræfter i dem selv og i samtiden, der trak dem fra hinanden, men der var også en modbevægelse, der kunne have bragt dem sammen. Det fik Kierkegaard definitivt forpurret med sit verbale, selvmorderiske overfald på Grundtvig i et af de sidste numre af Øieblikket (s. 220).

Det var dog nok ødelagt allerede på et lidt tidligere tidspunkt af kirkekampen.

Sven Erik Werner har foræret mig en fremragende slutsætning til denne anmeldelse: "Den historisk betingede, men også kunstigt skabte polarisering mellem Grundtvig og Kierkegaard hører til Danmarkshistoriens største dumheder" (s. 222). 